\title{
Aflatoxins in Pistachios Consumed in Mexico
}

\section{Gavilán-Ruiz $\mathrm{JM}^{1}$, Carvajal-Moreno $\mathbf{M}^{\mathbf{1}^{*}}$, Rojo-Callejas $\mathrm{F}^{2}$ and Ruiz-Velasco $\mathrm{S}^{3}$}

${ }^{1}$ Mycotoxins Laboratory, Department of Botany, Institute of Biology, National Autonomous University of Mexico (UNAM). 04510 Mexico, DF ${ }^{2}$ Department of Analytical Chemistry, Faculty of Chemistry, UNAM. 04510 Mexico, DF

${ }^{3}$ Department of Probability and Statistics, Institute of Research in Applied Mathematics and Systems, UNAM. 04510 Mexico, DF

\section{Abstract}

Introduction Aflatoxins (AFs) are fungal secondary metabolites with potent carcinogenic properties' and pistachios are susceptible oilseeds for AF contamination.

Objective To determine the concentration of the four $A F s$ types $\left(\mathrm{AFB}_{1}, \mathrm{AFB}_{2}, \mathrm{AFG}_{1}\right.$ and $\mathrm{AFG}_{2}$ ) from 48 pistachio samples from Mexico, six from Turkey and three from Greece.

Methods The AFs of the 57 analysed samples of pistachio seeds were quantified by liquid chromatography. The calibration curves had $R^{2}$ values near 1 . The LOD values were low and were acceptable to identify and quantify the AFs. The recovery percentages were $>80 \%$, which indicated that the extraction method was efficient, and in the selectivity test, no interference between the retention times of the AFs and the pistachio matrix were observed.

Results This study validated an analytical method developed to quantify AFs in pistachios. All samples were contaminated with trace levels of AFs. A total of $36.4 \%$ were contaminated with AFB $1(0.10$ to $4.15 \mathrm{ng} / \mathrm{g}), 100 \%$ of the samples had both $A F B_{2}\left(0.01\right.$ to $4.00 \mathrm{ng} / \mathrm{g}$ ) and $A F G_{1}(0.02$ to $1.02 \mathrm{ng} / \mathrm{g}), 56.4 \%$ had $A F G_{2}(0.46$ to $8.09 \mathrm{ng} / \mathrm{g}$ ) and $100 \%$ were contaminated with total aflatoxin $(\mathrm{AFt})(0.04$ to $8.39 \mathrm{ng} / \mathrm{g})$. The samples most contaminated with $\mathrm{AFB}_{1}(4.15$ $\mathrm{ng} / \mathrm{g})$ and $\mathrm{AFG}_{1}(1.02 \mathrm{ng} / \mathrm{g})$, and with $\mathrm{AFB}_{2}(4.00 \mathrm{ng} / \mathrm{g})$ were from Mexico. The highest contamination by $\mathrm{AFG}_{2}(8.09$ $\mathrm{ng} / \mathrm{g})$ and $\mathrm{AFt}(8.39 \mathrm{ng} / \mathrm{g})$ was in one sample from Istanbul, Turkey.

Conclusion All the samples resulted contaminated with AFs although the levels do not risk the health because they are below the tolerance levels of World Health Organization $\left(5 \mu \mathrm{g} \mathrm{kg}^{-1}\right.$ for AFB ${ }_{1}$ and $10 \mu \mathrm{g} \mathrm{kg}^{-1}$ for AFt) and Food and Agriculture Organization of United Nations (FAO) $\left(20 \mu \mathrm{gg}^{-1}\right.$ for AFB ${ }_{1}$ and $35 \mathrm{\mu g} \mathrm{kg}^{-1}$ for AFt). There was a significant difference between the AF content and the place of origin of the samples.

Keywords: Pistachios; Aflatoxins; Contamination; Toxicology; Carcinogens; Mutagens

\section{Introduction}

Pistachios are consumed and exported raw, toasted and salted for use in desserts, ice creams, aromatisers, condiments and sweets [1]. The main countries of production are Iran, the United States, Turkey, and China; however, Mexico produced 38 tons and was in the $18^{\text {th }}$ position in 2012 [2]. Aspergillus flavus, A. parasiticus [3], A. pseudotamarii [4], A. bombycis [5], A. tamarii [6] and A. ochraceoroseus [6] are moulds that produce aflatoxins (AFs), and they have an affinity for oil seeds, including pistachios. AFs are potent mutagens, carcinogens [7] and teratogens [8] that can cause acute effects, called aflatoxicoses, when consumed in mg quantities. These aflatoxicoses have several symptoms, such as bleeding, diarrhoea, liver disease, oedema, digestion alteration, changes in food metabolism and occasionally death [9]. Chronic effects are produced when AFs are consumed in $\mu \mathrm{g}$ or ng amounts, such as low nutrient absorption, slow growth, immunodepression, low response to vaccination, cancer, Reye syndrome, hepatitis, cirrhosis, Kwashiorkor or protein malnutrition and kidney problems. Epidemiological studies from Europe, Africa and Asia indicate that there is a positive correlation between liver cancer and the consumption of AF contaminated foods [10]. $\mathrm{AFB}_{1}$ is metabolized in the liver, where it is hydroxylated to form aflatoxin $\mathrm{P}_{1}\left(\mathrm{AFP}_{1}\right)$, aflatoxin $\mathrm{M}_{1}\left(\mathrm{AFM}_{1}\right)$ and aflatoxin $\mathrm{Q}_{1}\left(\mathrm{AFQ}_{1}\right)$. $\mathrm{AFB}_{1}$ can also be oxidated to link with DNA, RNA and proteins as the unstable $\mathrm{AFB}_{1}-8,9$-epoxide, which affects cell transcription and translation. When this epoxide links to nitrogen $7\left(\mathrm{~N}^{7}\right)$ of guanine DNA residues, it forms an 8, 9-dihydro-8-( $\mathrm{N}^{7}$-guanyl)-9-hydroxyaflatoxin $\mathrm{B}_{1}$ $\left(\mathrm{AFB}_{1}-\mathrm{N}^{7}\right.$-Gua) adduct. This adduct interferes with transcription and diminishes ribonucleic acid synthesis, and it can produce a mutation or initialise cancer [10]. Moreover, the liver is the organ that forms and accumulates most of the $\mathrm{AFB}_{1}-\mathrm{ADN}$ adducts. Approximately 5 and $10 \%$ of crops worldwide are spoiled by moulds and consequently must not be consumed by animals or humans. During the field growth and also post-harvest storage of pistachios (Pistacia vera L.), AF contamination produces health risks and economic losses [1]. Pistachios have a high risk of AF contamination [11,12] because of the open shell and premature pistachio opening that increase insect damage. In 2006, Iran detected that $37 \%$ of their pistachio crops had an $\mathrm{AFB}_{1}$ contamination of $5.9 \pm 41.7 \mathrm{ng} / \mathrm{g}$ and $28 \%$ had an average total aflatoxin (AFt) level of $7.3 \pm 53.2 \mathrm{ng} / \mathrm{g}$ [13]. In 2013, Iran had $23 \%$ of their pistachio crop contaminated with $\mathrm{AFB}_{1}(2.18 \pm 13.1 \mathrm{ng} / \mathrm{g})$ and 24 $\%$ with an average AFt level of $2.42 \pm 14.7 \mathrm{ng} / \mathrm{g}$ [14]. In 2008, Morocco detected $45 \%$ contamination of their pistachios with $\mathrm{AFB}_{1}(158 \pm 6.3$ $\mathrm{ng} / \mathrm{g}$ ) and $45 \%$ presented an average AFt level of $163 \pm 5.4 \mathrm{ng} / \mathrm{g}$ [11]. In 2009, Tunisia detected a 53\% pistachio contamination with AFt $(21.8$ $\pm 38.0 \mathrm{ng} / \mathrm{g}$ ) [15]. There are also reports regarding AF contamination in foods from markets in Spain [16]. Mexico had a population of $112,336,538$ in 2010 and a population density of 5920.5 inhabitants per $\mathrm{km}^{2}$ with $>18 \%$ of its population living in Mexico City, which includes the capital city or Federal District and the surrounding State of Mexico. Together, these both made a city of 20.4 million in 2012 [17], which is four times the population of Norway or Denmark and twice the

*Corresponding author: Carvajal-Moreno M, Laboratorio de Micotoxinas. Departamento de Botánica, Instituto de Biología, Universidad Nacional Autónoma de México (UNAM), 04510 México, DF. Tel: 5255-5622-9138; Fax: 5255-5550-1760; E-mail: magdac@ib.unam.mx

Received April 15, 2015; Accepted April 29, 2015; Published May 05, 2015

Citation: Gavilán-Ruiz JM, Carvajal-Moreno M, Rojo-Callejas F, Ruiz-Velasco S (2015) Aflatoxins in Pistachios Consumed in Mexico. Nat Prod Chem Res 3: 174 doi:10.4172/2329-6836.1000174

Copyright: ( 2015 Gavilán-Ruiz JM. This is an open-access article distributed under the terms of the Creative Commons Attribution License, which permits unrestricted use, distribution, and reproduction in any medium, provided the original author and source are credited. 
population of Sweden. Mexico City is the third most populated city in the world after Tokyo and Delhi [18]. The Federal District is divided in 16 boroughs that receive food from all around the country, which makes it a reliable sampling place to obtain an idea of the pistachios consumed in the entire country. The population of the 16 boroughs in 2010 [19] is shown in Table 1. To date, there are no data regarding the pistachio consumption in Mexico and its comparison with foreign producer countries. The purpose of the research herein is to identify and quantify the $A F s\left(B_{1}, B_{2}, G_{1}\right.$ and $\left.G_{2}\right)$ in pistachio seeds from Mexico City, and some samples from Istanbul (Turkey) and Santorini (Greece) using high performance liquid chromatography (HPLC). Despite aflatoxin contamination having been observed in several foodstuffs, the contamination of maize, peanuts, and oilseeds can be considered, in terms of diet exposure, the most important worldwide [20].

\section{Materials and methods}

\section{Sampling}

As a result of variable conditions that can occur during pre and postharvest, the aflatoxin contamination level among cereal grains and nuts such as peanuts, almonds, Brazil nuts, and pistachios within the same lot can have an extremely uneven distribution [21-24]. In a contaminated lot, just a few grains and nut kernels can have quite high concentration levels of aflatoxin, and most of them do not have detectable contamination [25].

The pistachios in shells of each market were placed in numerous saks of $20 \mathrm{~kg}$ each. Each sample was obtained taking pistachios with shell from different saks. The sample size of $100 \mathrm{~g}$ is accepted in the case of surveys, only bigger amounts are reccommended for international commerce burden [23]. In order to have a survey of the AF in pistachios of Mexico City, $100 \mathrm{~g}$ of samples of shelled natural pistachios were purchased from August 29 to September 13, 2012, from the three most important markets from each one of the 16 boroughs of Mexico City, which resulted in a total of 48 samples from 48 different markets. The pistachios were shelled and ground to powder and, in the case of
Mexican pistachios, three subsamples (17 g), from each one of the three markets of the borough, were mixed to make a combined sample that represented the borough. Later each combined sample was blended (Black \& Decker Mod. Crush Master, Mod. V2350BP) with methanol/ water $(80: 20 \mathrm{v} / \mathrm{v})$ for chemical analysis.

Sampling in Turkey and Greece: Six $100 \mathrm{~g}$ samples from different stores at the Spices Bazaar of Istanbul, Turkey were purchased on August $8^{\text {th }}, 2010$ and three samples, each of $100 \mathrm{~g}$, from the market of Santorini, Greece were purchased on July $27^{\text {th }}, 2010$, and were analysed. All samples were frozen in Mexico upon arrival.

\section{Validation of the method $[26,27]$}

Linearity (Calibration curves): The four AF calibration curves were obtained from separate one $\mu \mathrm{g} / \mathrm{mL}$ stock solutions of $\mathrm{AFB}_{1}$, $\mathrm{AFB}_{2}, \mathrm{AFG}_{1}$ and $\mathrm{AFG}_{2}$ (Sigma-Aldrich, St. Louis, MO, USA). The AF standards were dissolved in one $\mathrm{mL}$ of benzene: acetonitrile $(98: 2, \mathrm{v} / \mathrm{v})$ as suggested by the Official Method of Analyses AOAC 970.44 for aflatoxins [26-28] and then they were homogenised (Vortex 2 Genie Model G-560; 120 volts, 0.5 amperes, 60 hertz). Finally, one mL of each AF was diluted in HPLC grade $\mathrm{MeOH}$ and labelled.

The absorbance of the AF solutions in $\mathrm{MeOH}$ was measured at 362 $\mathrm{nm}$ in a spectrophotometer (Genesys, 10 UV Model, Thermo Electron Corporation, West Palm Beach, and FL33407 United States) to obtain the one $\mu \mathrm{g} / \mathrm{mL}$ stock solution with different molecular weights and extinction coefficients [28].

Each AF standard had several dilutions $(0.01,0.05,0.1,0.5,1,2,4$, $5,8,10,16,20,32,40,64,70,100,128,200,600,800$, and $1000 \mathrm{ng} / \mathrm{mL}$ ) that were dried in an oven at $40^{\circ} \mathrm{C}$ (Novatech BTC-9100). To derivatise the AF standard, $200 \mu \mathrm{L}$ of ACN with $800 \mu \mathrm{L}$ of derivatising solution were added. The derivatising solution had $5 \mathrm{~mL}$ of trifluoroacetic acid (TFA) (Sigma-Aldrich, St. Louis MO, USA) with $2.5 \mathrm{~mL}$ of glacial acetic acid (Merck, Naucalpan, State of Mexico, Mexico) and $17.5 \mathrm{~mL}$ of deionised distilled water. The mixture, in an amber vial, was shaken for 30 seconds and then heated at $65^{\circ} \mathrm{C}$ for $10 \mathrm{~min}$ in a steam bath [29].

\begin{tabular}{|c|c|c|c|c|c|c|c|c|}
\hline \multirow{2}{*}{ Average AF of Mexican 1-48 samples } & \multirow{2}{*}{ Country } & \multirow{2}{*}{ Borough/nhabitants in 2010} & \multicolumn{6}{|c|}{ AF $(n g / g)$ concentration mean rate } \\
\hline & & & $\mathrm{AFB}_{1}$ & $\mathrm{AFB}_{2}$ & $\mathrm{AFG}_{1}$ & $\mathrm{AFG}_{2}$ & AFt & Average \\
\hline $1-3$ & \multirow{16}{*}{ México } & Álvaro Obregón/727,034 & $<L O D$ & 0.03 & 0.07 & 1.07 & 1.17 & 0.29 \\
\hline 4-6 & & Azcapotzalco/414,711 & 0.08 & 0.26 & 0.26 & 0.60 & 1.05 & 0.26 \\
\hline $7-9$ & & Benito Juárez/385,439 & 0.41 & 0.07 & 0.12 & 1.27 & 1.87 & 0.47 \\
\hline $10-12$ & & Coyoacán/620,416 & $<L O D$ & 0.06 & 0.03 & 0.75 & 0.84 & 0.22 \\
\hline $13-15$ & & Cuajimalpa de Morelos/186,391 & 0.07 & 0.08 & 0.05 & 0.41 & 0.62 & 0.16 \\
\hline $16-18$ & & Cuauhtémoc/531,831 & $<L O D$ & 0.09 & 0.03 & 0.79 & 1.25 & 0.23 \\
\hline $19-21$ & & Gustavo A. Madero/1,185,772 & 0.06 & 0.28 & 0.03 & 0.22 & 0.60 & 0.15 \\
\hline $22-24$ & & Iztacalco/384,326 & $<L O D$ & 0.55 & 0.03 & $<L O D$ & 0.58 & 0.14 \\
\hline $25-27$ & & Iztapalapa/1,815,786 & 0.17 & 0.16 & 0.12 & $<L O D$ & 0.46 & 0.49 \\
\hline $28-30$ & & La Magdalena Contreras/239,086 & 0.25 & 0.05 & 0.06 & 0.67 & 1.03 & 0.26 \\
\hline $31-33$ & & Miguel Hidalgo/372,889 & 1.66 & 0.03 & 0.28 & 0.33 & 1.70 & 0.43 \\
\hline $34-36$ & & Milpa Alta/130,582 & $<L O D$ & 0.03 & 0.04 & 0.17 & 0.24 & 0.06 \\
\hline $37-39$ & & Tláhuac/360,265 & $<L O D$ & 0.04 & 0.04 & 0.27 & 0.35 & 0.09 \\
\hline $40-43$ & & Tlalpan/650,567 & 0.11 & 0.03 & 0.06 & 0.39 & 1.00 & 0.18 \\
\hline $43-45$ & & Venustiano Carranza/430,978 & 0.04 & 0.27 & 0.03 & 1.97 & 2.31 & 0.58 \\
\hline $46-48$ & & Xochimilco/415,007 & 1.56 & 0.51 & 0.38 & 0.85 & 4.26 & 1.08 \\
\hline \multicolumn{9}{|c|}{ Average AF of samples from: } \\
\hline $1-48$ & Mexico & $\begin{array}{c}48 \text { markets, } 3 \text { from each one of } 16 \\
\text { boroughs. }\end{array}$ & 0.24 & 0.22 & 0.09 & 0.62 & 1.17 & 0.30 \\
\hline $49-54$ & Turkey & Spices Bazaar & 0.22 & 0.04 & 0.07 & 3.00 & 3.33 & 0.87 \\
\hline $55-57$ & Greece & Santorini market & 0.13 & 0.18 & 0.11 & 2.05 & 2.46 & 0.62 \\
\hline
\end{tabular}

"One sample of $300 \mathrm{~g}$ divided in 3 subsamples of $100 \mathrm{~g}$. <LOD are traces that count as zero.

Table 1: Aflatoxins in pistachio in Mexico City, Turkey and Greece. 
Sixty $\mu \mathrm{L}$ were injected in the HPLC in triplicate. The equations for the calibration curves and the correlation coefficients $\left(\mathrm{R}^{2}\right)$ were obtained with Excel.

The limits of detection (LOD) were determined using the minimal concentration of the AF standard detected in the calibration curve. The limit of quantification (LOQ) was considered to be five times the value of the LOD [27].

Recovery rates: From $\mathrm{AF}$ standard, $\mathrm{AFB}_{1}, \mathrm{AFB}_{2}, \mathrm{AFG}_{1}, \mathrm{AFG}_{2}$, concentration of $1000 \mathrm{ng} / \mathrm{mL}$, three concentrations (2, 10 and 100 $\mathrm{ng} / \mathrm{g}$ ) were independently prepared to spike five replications, of one gram of ground pistachio each, from a stock that had different basal $\mathrm{AF}$ concentrations. Basal contamination of the stock ground pistachio had $0.02 \mathrm{ng} / \mathrm{g}$ of $\mathrm{AFB}_{1}, 0.03 \mathrm{ng} / \mathrm{g}$ of $\mathrm{AFB}_{2}, 0.02 \mathrm{ng} / \mathrm{g}$ of $\mathrm{AFG}_{1}$ and $0.32 \mathrm{ng} / \mathrm{g}$ of $\mathrm{AFG}_{2}$. The five replications were done independently as suggested [28]. Each replication of one gram of ground pistachio was independently weighed and placed in $50 \mathrm{~mL}$ centrifuge tubes (Falcon). Each one gram of ground pistachio replications was spiked with the AF standard mentioned concentrations and three $\mathrm{mL}$ of $\mathrm{MeOH}$, one gram of $\mathrm{NaCl}$ and $2 \mathrm{~mL} \mathrm{H}_{2} \mathrm{O}_{\mathrm{d}}$, were added and the solution was centrifuged at $4000 \mathrm{rpm}$ (ALC 4235 with CWS freezing system) for $15 \mathrm{~min}$. The supernatants were recovered, and then they were diluted in phosphate buffer (PBS) (1:4, v/v) pH adjusted to 7.4.

The diluted supernatant, equivalent to one gram of pistachio, was applied to a total aflatoxins (AFt) immunoafffinity column (EasiExtract R-Biopharm Rhône LTD, UK) that was previously equilibrated with PBS $(20 \mathrm{~mL})$ at a speed of one drop per second.

The immunoafffinity column was washed with $20 \mathrm{~mL}$ of distilled water, and eluted with HPLC grade $\mathrm{MeOH}(1.5 \mathrm{~mL})$ and distilled water $(1.5 \mathrm{~mL})$ by gravity into a labelled amber vial that was dried at $40^{\circ} \mathrm{C}$, derivatised and injected for HPLC analysis in triplicate ( $60 \mu \mathrm{L}$ aliquots).

Selectivity: To confirm that the AFs had no interference with the pistachio matrix, a mixture of the four AF standards, dissolved in $\mathrm{MeOH}(3 \mathrm{~mL})$ with one gram of $\mathrm{NaCl}$ and $2 \mathrm{~mL}$ of $\mathrm{H}_{2} \mathrm{O}_{\mathrm{d}}$ was measured alone and also applied to one ground pistachio samples $(1 \mathrm{~g})$, in a 50 $\mathrm{mL}$ centrifuge tube (Falcon) and centrifuged at $4000 \mathrm{rpm}$ for $15 \mathrm{~min}$. This procedure [26] was repeated to obtain a total of four replicates.

The supernatant, diluted in PBS $(1: 4, \mathrm{v} / \mathrm{v})$ at $\mathrm{pH} 7.4$, was applied to the immunoafffinity column in the same way as mentioned before [28]. The eluates were dried in an oven at $40^{\circ} \mathrm{C}$, derivatised and injected $(60$ $\mu \mathrm{L}$ aliquots) into the HPLC in triplicate.

Sample extraction method: Following known methods [30,31], $50 \mathrm{~g}$ of ground pistachio were blended with $100 \mathrm{~mL}$ of a methanol: water mixture $(80: 20, \mathrm{v} / \mathrm{v})$ and $2 \mathrm{~g}$ of $\mathrm{NaCl}$, and then filtered using fine pore paper. Then, the filtrate $(2 \mathrm{~mL})$ was diluted in $14 \mathrm{~mL}$ of PBS, and this mixture was applied to an equilibrated immunoafffinity column at slow flow rate, and washed with $20 \mathrm{~mL}$ of $\mathrm{H}_{2} \mathrm{O}_{\mathrm{d}}$. The sample was eluted by gravity with $1.5 \mathrm{~mL}$ of HPLC grade $\mathrm{MeOH}$ followed by $1.5 \mathrm{~mL}$ of $\mathrm{H}_{2} \mathrm{O}_{\mathrm{d}}$ with reflux. The eluate $(3 \mathrm{~mL})$ was dried in an oven at $40^{\circ} \mathrm{C}$, and derivatised as mentioned previously [29].

Chromatographic conditions: The mobile phase was $\mathrm{H}_{2} \mathrm{O}: \mathrm{ACN}$ : $\mathrm{MeOH}(65: 15: 20, \mathrm{v} / \mathrm{v} / \mathrm{v})$ at a flow rate of one $\mathrm{mL} / \mathrm{min}$. The fluorescence was detected at an excitation wavelength of 360-362 nm and emission of $425 \mathrm{~nm}$ for $\mathrm{AFB}_{1}$ and $\mathrm{AFB}_{2}$, and an emission wavelength of 450 $\mathrm{nm}$ for $\mathrm{AFG}_{1}$ and $\mathrm{AFG}_{2}$. ChemStation 32 was the program used for HPLC quantitation using a liquid chromatography (Series 1200) with an isocratic pump (G1310A Series DE62957044), fluorescence detector (G1321A Series DE 60456380) and autosampler (G1329A
Series DE64761666), which were all from Agilent Technologies. The chromatographic column was a $4.6 \times 250 \mathrm{~mm}$ Agilent Eclipse XDS-C18 with a $5 \mu \mathrm{m}$ particle size.

AF sample quantification by HPLC: Sixty $\mu \mathrm{L}$ of derivatised eluate were applied in triplicate to quantify the AFs by HPLC. Utilising the areas and equations of each curve, the corresponding AF concentration was calculated $(\mathrm{ng} / \mathrm{mL})$ and corrected by the percentage of recovery as follows [28];

Final corrected concentration $=100 \times$ AF concentration in sample Recovery \% of AF

\section{Statistical analyses}

Kruskal-Wallis non-parametric statistical tests were used to analyse the data and compare the samples to check the relationship between concentration of AFs in the pistachios and their purchase sampling source. Later, a Wilcoxon range test was performed to determine the significant differences.

\section{Results}

\section{Validation of the method}

The analytical method fulfilled the validation criteria of the EC Regulatory Commission 2004/882.

Linearity (calibration curves): The correlation coefficient $\left(\mathrm{R}^{2}\right)$ and slope equation of each $\mathrm{AF}$ were: $\mathrm{AFB}_{1}\left(\mathrm{R}^{2}=0.9973 \approx 1\right.$, slope $\mathrm{y}=2.8299$ $\mathrm{x}) ; \mathrm{AFB}_{2}\left(\mathrm{R}^{2}=0.9908 \approx 1\right.$, slope $\left.\mathrm{y}=1.7786 \mathrm{x}\right) ; \mathrm{AFG}_{1}\left(\mathrm{R}^{2}=0.9969 \approx 1\right.$, slope $y=1.7607 x$ and $A F G_{2}\left(R^{2}=0.9986 \approx 1\right.$, slope $\left.y=1.2411 x\right)$. The retention times of the different validation parameters were compared to determine the accepted one for each AF: $\mathrm{AFB}_{1}$ 7.612-8.919 min, $\mathrm{AFB}_{2}$ 17.590-19.804 min, AFG 5.642-6.447 min, $\mathrm{AFG}_{2}$ 11.319-13.247 $\min$.

Limit of detection (LOD) and limit of quantification (LOQ): The respective $\mathrm{LOD}$ and $\mathrm{LOQ}$ values were: $\mathrm{AFB}_{1}(0.1$ and $0.5 \mathrm{ng} / \mathrm{g}), \mathrm{AFB}_{2}$ (0.01 and $0.05 \mathrm{ng} / \mathrm{g}), \mathrm{AFG}_{1}(0.01$ and $0.05 \mathrm{ng} / \mathrm{g})$ and $\mathrm{AFG}_{2}(0.5$ and 2.5 $\mathrm{ng} / \mathrm{g})$.

Recovery percentage: The AF extraction method in pistachios was efficient, with a recovery percentage media of $88.06 \%$ for $\mathrm{AFB}_{1}$, of 96.04 $\%$ for $\mathrm{AFB}_{2}$, of $88.82 \%$ for $\mathrm{AFG}_{1}$ and $89.79 \%$ for $\mathrm{AFG}_{2}$.

Selectivity test : The selectivity test was the analytical method to determine whether the matrix (pistachio) interfered with the detection of the AFs. The four AF standards had no pistachio matrix interference. The proposed method has the power to discriminate between $\mathrm{AFB}_{1}$, $\mathrm{AFB}_{2}, \mathrm{AFG}_{1}$ and $\mathrm{AFG}_{2}$, and other pistachio components. The $\mathrm{AF}$ from the blank standards (BS) in comparison to the AF from the matrix (AFM) were: $\mathrm{AFG}_{1}$ (BS $6.447 \mathrm{~min}$ and AFM $6.098 \mathrm{~min}$ ); AFB ${ }_{1}$ (BS 8.919 min and AFM $8.366 \mathrm{~min}$ ); $\mathrm{AFG}_{2}$ (BS $18.246 \mathrm{~min}$ and AFM $12.444 \mathrm{~min}$ ) and $\mathrm{AFB}_{2}$ (BS $19.804 \mathrm{~min}$ and $\mathrm{AFM} 18.490 \mathrm{~min}$ ) which were in the same range of retention times and the peaks did not overlapped.

\section{AF quantification in the pistachio samples}

The results of the AFs in the pistachio samples are in Table 1. In general, all samples were contaminated with two or more AFs in low or trace concentrations. The tolerance levels for OMS [32] are $5 \mu \mathrm{g} / \mathrm{kg}$ $\mathrm{AFB}_{1}$ and $10 \mu \mathrm{g} / \mathrm{kg} \mathrm{AFt}$ and for FAO (2004) [33] are 20 $\mu \mathrm{g} / \mathrm{kg} \mathrm{AFB}_{1}$ and $35 \mu \mathrm{g} / \mathrm{kg} \mathrm{AFt}$.

A total of $36.4 \%$ of the samples were contaminated with $\mathrm{AFB}_{1}(0.10$ to $4.15 \mathrm{ng} / \mathrm{g}$ ), $100 \%$ with $\mathrm{AFB}_{2}$ (0.01 to $4.00 \mathrm{ng} / \mathrm{g}$ ) and $\mathrm{AFG}_{1}(0.02$ to 
$1.02 \mathrm{ng} / \mathrm{g}$ ), $56.4 \%$ with $\mathrm{AFG}_{2}$ (0.46 to $8.09 \mathrm{ng} / \mathrm{g}$ ), and $100 \%$ with $\mathrm{AFt}$ $(0.04$ to $8.39 \mathrm{ng} / \mathrm{g})$. These concentrations are less than those reported in Iran [13], Morocco [11] and Tunisia [14].

In Mexico, the samples most contaminated with $\mathrm{AFB}_{1}$ were from the Mixcoac market in the Benito Juárez borough $(1.23 \mathrm{ng} / \mathrm{g})$, the Tacubaya market in the Miguel Hidalgo borough (3.20 ng/g; 5.01 ng/g AFt) and the Xochimilco market and in the Xochimilco borough (4.15 ng/g AFB $; 4.00 \mathrm{ng} / \mathrm{g} \mathrm{AFB}_{2} ; 1.02 \mathrm{ng} / \mathrm{g} \mathrm{AFG}$; and $7.04 \mathrm{ng} / \mathrm{g} \mathrm{AFt}$ ). $\mathrm{AFB}_{2}$ contamination was $1.38 \mathrm{ng} / \mathrm{g}$ in the samples from the San Miguel market in the Ixtacalco borough. Moreover, increased $\mathrm{AFG}_{2}(4.06$ $\mathrm{ng} / \mathrm{g}$ ) was found in the Merced market, in the Venustiano Carranza borough with high AFt (4.43 ng/g). Sample 52 from the Spices Bazaar in Istanbul, Turkey had contamination with $\mathrm{AFG}_{2}(8.09 \mathrm{ng} / \mathrm{g})$ and an AFt value of $8.39 \mathrm{ng} / \mathrm{g}$. The 3 samples from Greece had AFt $2.46 \mathrm{ng} / \mathrm{g}$ that increased from $\mathrm{AFG}_{2} 2.05 \mathrm{ng} / \mathrm{g}$ (Table 1).

\section{Statistical analyses}

The Kruskal-Wallis and the Wilcoxon range tests found statistically significant differences $(<0.05)$ in the concentrations of $\mathrm{AFB}_{1}, \mathrm{AFB}_{2}$, $\mathrm{AFG}_{1}, \mathrm{AFG}_{2}$ and $\mathrm{AFt}$ of the pistachio samples and their origin, with the following $\mathrm{AF}$ (statistical values): $\mathrm{AFB}_{1}$ (67.6629), $\mathrm{AFB}_{2}$ (64.1586), $\mathrm{AFG}_{1}$ (60.4021), $\mathrm{AFG}_{2}$ (53.2218) and AFt (58.1913).

$\mathrm{AFB}_{1}$ is the most mutagenic, teratogenic and carcinogenic compound of all AFs [9]. The Xochimilco borough samples (1.56 $\mathrm{ng} / \mathrm{g}$ ) are significantly different from the rest, except for those from the Benito Juárez borough $\left(0.41 \mathrm{ng} / \mathrm{g}\right.$ ) (Figure 1a). For $\mathrm{AFB}_{2}$ (Figure 1b), the Xochimilco samples $(1.51 \mathrm{ng} / \mathrm{g}$ ) were again different from the rest, except for those from Azcapotzalco $(0.26 \mathrm{ng} / \mathrm{g})$, Venustiano Carranza $(0.27 \mathrm{ng} / \mathrm{g})$, G.A. Madero (0.29 ng/g) and Iztacalco (0.54 ng/g). For $\mathrm{AFG}_{1}$ (Figure 2a), the Xochimilco $(0.38 \mathrm{ng} / \mathrm{g})$ and Miguel Hidalgo $(0.27 \mathrm{ng} / \mathrm{g})$ boroughs were the most contaminated and different from the remaining ones, except the Azcapotzalco ( $0.10 \mathrm{ng} / \mathrm{g}$ ), Benito Juárez $(0.11 \mathrm{ng} / \mathrm{g})$ and Iztapalapa $(0.12 \mathrm{ng} / \mathrm{g})$ boroughs as well as Santorini, Greece $(0.11 \mathrm{ng} / \mathrm{g})$. For $\mathrm{AFG}_{2}$ (Figure $\left.2 \mathrm{~b}\right)$, the Santorini sample $(2.05$ $\mathrm{ng} / \mathrm{g}$ ) was the most contaminated and it was significantly different from the remaining ones, except the Cuauhtémoc ( $0.69 \mathrm{ng} / \mathrm{g})$, Álvaro Obregón (0.71 ng/g), Benito Juárez (1.15 ng/g), Venustiano Carranza $(1.52 \mathrm{ng} / \mathrm{g})$ boroughs and Istanbul, Turkey $(1.8 \mathrm{ng} / \mathrm{g})$.

For AFt (Figure 3), the Xochimilco $(4.08 \mathrm{ng} / \mathrm{g}$ ) and Santorini $(2.47 \mathrm{ng} / \mathrm{g})$ boroughs were the most contaminated, with significant differences from the rest, except the Azcapotzalco $(0.88 \mathrm{ng} / \mathrm{g})$, Benito Juárez (1.75 ng/g), and Venustiano Carranza (1.84 ng/g) boroughs and Istanbul, Turkey $(2.07 \mathrm{ng} / \mathrm{g})$.

\section{Discussion}

Pistachios are both a nutrient and a health risk. The present study helps humans to know the state of their pistachio, to prevent and avoid aflatoxins.A study [34] of Aspergillus molds in California pistachios, early split nuts had over $99 \%$ of the aflatoxin detected and navelorangeworm-infected nuts had substantially more infection by several Aspergillus species, as well as over $84 \%$ of the aflatoxin detected. Also early splits with rough hulls had substantially more AF than early splits with smooth hulls [34]. AF levels were significantly lower in wounded kernels with hulls than in kernels of hulled pistachios. Both the seed coat and a water-soluble extract of hulls suppressed AF production by A. flavus [35].

The pistachio is an oilseed that is highly contaminated with AFs worldwide, and although the AF concentration in one gram of pistachio in Mexico is under the tolerance level to produce a mutation, which is (a)

Comparison between the place of origin and AFB1 (ng/g) content

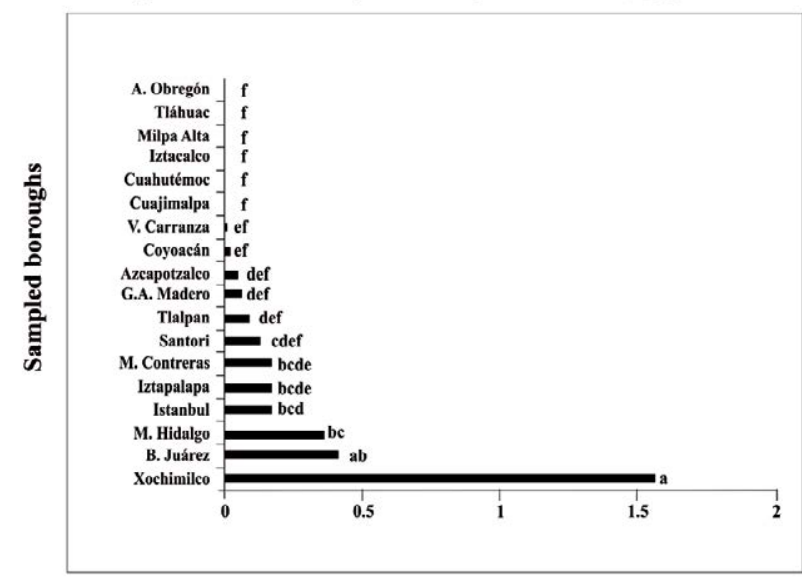

Concentration medias of AFB1 (ng/g)

(b)

Comparison between the place of origin and AFB2 (ng/g) content

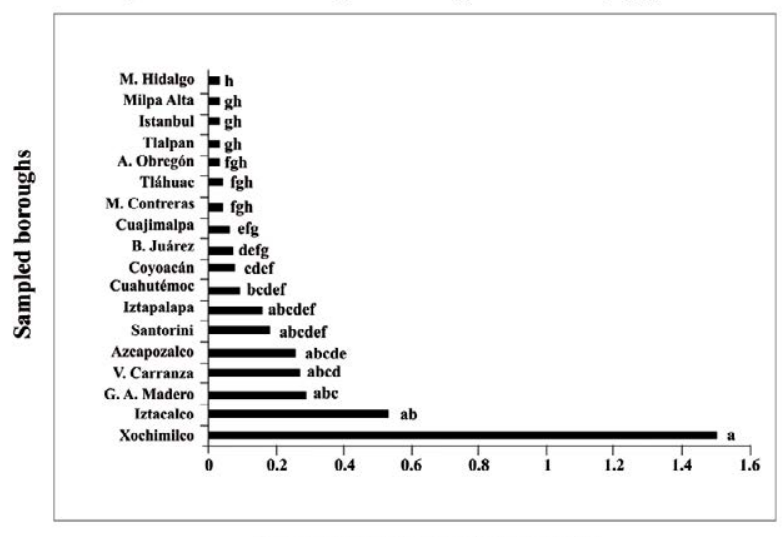

Concentration medias of AFB2 (ng/g)

Figure 1: Wilcoxon/Kruskal-Wallis statistical test. Comparison between a) AFB1 concentration and purchase source, b) AFB2 concentrations and their purchase origin. Absence of common letters means a significant difference between samples.

$10 \mathrm{ng} / \mathrm{g}$ [36], the amounts consumed are much higher. Mold counts on nuts going into storage can be high [37], it is important that proper storage conditions (especially low relative humidity and absence of standing water) be maintained to avoid serious problems.

The Aspergillus mould attacks the pistachio both before harvest when the fruits are still in the tree and afterwards when the pistachios are in storage [38]. In addition, the early opening of the pistachio shell before harvest favours spore contamination by air or by insects. AF contamination is exacerbated by long-term storage with unhygienic conditions, such as high temperatures and increased humidity. The presence of $\mathrm{AFB}_{1}, \mathrm{AFB}_{2}, \mathrm{AFG}_{1}$ and $\mathrm{AFG}_{2}$ in the samples shows an invasion by Aspergillus parasiticus as well as Aspergillus flavus, the main producers [39], but no identification of the other species [40] was done.There was a higher contamination of the samples with $\mathrm{AFG}_{2}$ than with $\mathrm{AFB}_{1}$, which is the most mutagenic, teratogenic and carcinogenic of all AFs, in agreement with the results of other studies [9]. When $A$. parasiticus grows in a medium with a $\mathrm{pH}<6.0$, AF Group $\mathrm{B}$ synthesis is favoured, and with $\mathrm{pH}>6.0, \mathrm{AF}$ group $\mathrm{G}$ synthesis is stimulated 
(a)

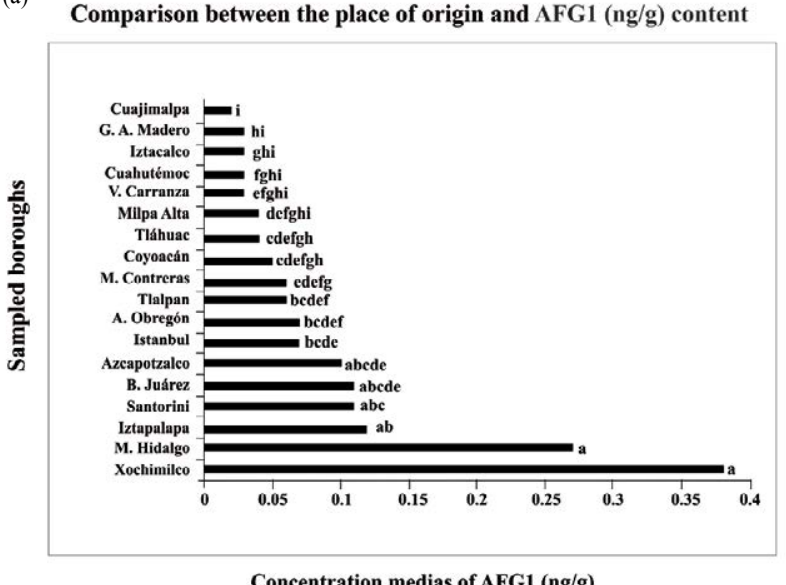

(b)

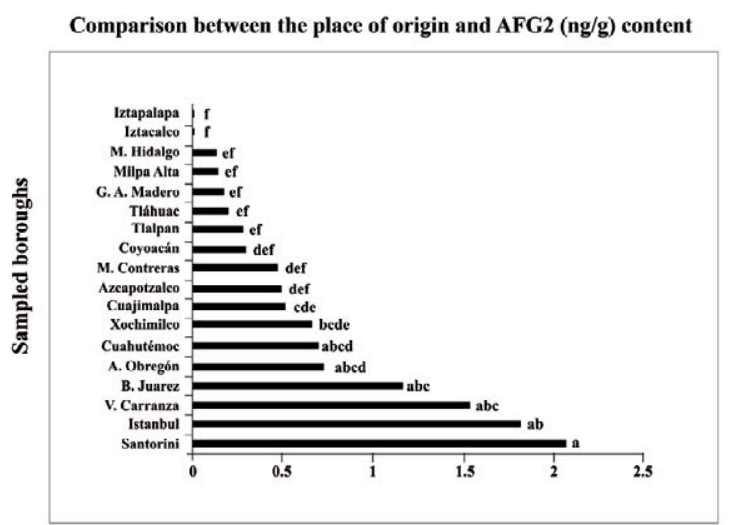

Concentration medias of AFG2 (ng/g)

Figure 2: Wilcoxon /Kruskal-Wallis statistical test. Comparison between a) AFG1 concentration and their origin, b) AFG2 concentrations and their origin. Absence of common letters means a significant difference between samples.

[41]. In our case, it is possible that the pistachio $\mathrm{pH}$ was $>6.0$, so after A. parasiticus invasion, the AF synthesis of group $\mathrm{G}$, specifically $\mathrm{AFG}_{2}$, occurred. All 57 pistachio samples (100\%) from Mexico, Turkey and Greece were contaminated with AF; however, they were below the permitted levels given by OMS $\left(5 \mu \mathrm{g} / \mathrm{kg}\right.$ for $\mathrm{AFB}_{1}$ and $10 \mu \mathrm{g} / \mathrm{kg}$ for AFt) and by FAO $\left(20 \mu \mathrm{g} / \mathrm{kg}\right.$ for $\mathrm{AFB}_{1}$ and $35 \mu \mathrm{g} / \mathrm{kg}$ for AFt $)$. A total of 36.4 $\%$ of the samples were contaminated with $\mathrm{AFB}_{1}(0.10$ to $4.15 \mathrm{ng} / \mathrm{g})$, $100 \%$ with $\mathrm{AFB}_{2}$ (0.01 to $4.00 \mathrm{ng} / \mathrm{g}$ ), $100 \%$ with $\mathrm{AFG}_{1}$ (0.02 to 1.02 $\mathrm{ng} / \mathrm{g}), 56.4 \%$ with $\mathrm{AFG}_{2}(0.46$ to $8.09 \mathrm{ng} / \mathrm{g})$ and $100 \%$ with $\mathrm{AFt}(0.04 \mathrm{a}$ $8.39 \mathrm{ng} / \mathrm{g}$ ).The most contaminated samples were from the Xochimilco market in the Xochimilco borough for $\mathrm{AFB}_{1}(4.15 \mathrm{ng} / \mathrm{g})$ and $\mathrm{AFG}_{1}$ $(1.02 \mathrm{ng} / \mathrm{g})$, from the Tulyehualco market in the Xochimilco borough for $\mathrm{AFB}_{2}(4.00 \mathrm{ng} / \mathrm{g})$, and from the Spices Bazaar market of Istanbul, Turkey for $\mathrm{AFG}_{2}(8.09 \mathrm{ng} / \mathrm{g})$ and $\mathrm{AFt}(8.39 \mathrm{ng} / \mathrm{g})$. There was a statistically significant difference between the content of $A F\left(B_{1}, B_{2}, G_{1}, G_{2}\right.$ and $\mathrm{AFt}$ ) and the purchase origin of the samples. This oilseed is recognised as part of a healthy diet because they contain monounsaturated and polyunsaturated fats, which protect humans against heart diseases and reduce total cholesterol $[42,43]$. All pistachios samples are also a health risk, because most of them are contaminated with aflatoxins that are proven carcinogens. In the millions of years of co-existing together, it seems that the pistachio plants have developed high amounts of antioxidants as a reaction against the mould and its aflatoxins, such
Comparison between the place of origin and AFt (ng/g) content

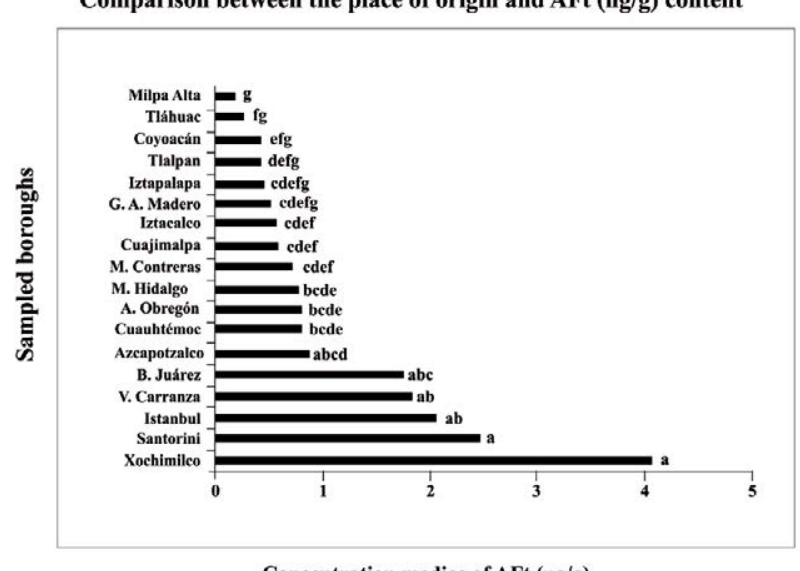

Figure 3: Wilcoxon /Kruskal-Wallis statistical test. Comparison of AFt concentration and their origin. Absence of common letters means a significant difference between samples.

as caffeic acid that reduces the AFs by $99.5 \%$, quinic acid (90.2 \%) and chlorogenic acid (88.5\%) [44]. Therefore, beneficial components, such as the antioxidants, and dangerous toxins appear together. The concentration of AFt found appears low, the homogenization was thorough and the analysed gram was representative, and a package of $100 \mathrm{~g}$ would have an average of $83 \mathrm{ng} \mathrm{AFt} / 100 \mathrm{~g}$ from Turkish pistachios or $30 \mathrm{ng} \mathrm{AFt} \mathrm{/100} \mathrm{g} \mathrm{from} \mathrm{Mexican} \mathrm{pistachios.} \mathrm{The} \mathrm{metabolic}$ activation of $\mathrm{AFB}_{1}$ initiates the adduct formation that origins cancer. $\mathrm{AFB}$ links to proteins such as albumin, ovalbumin, DNA and RNA, forming conjugates and adducts that can be detected in blood, urine and tissues of the organisms that ingested aflatoxins [45]. Adducts in tissues are the chronic exposition measure to aflatoxins and show the attack that DNA suffers in years of exposition. The presence of one adduct in $1,000,000$ nucleotides is the measure of the malignicity of tumors in rat fed with $\mathrm{AFB}_{1}[46]$. As soon as a person gets old, his DNA accumulates more adducts capable of producing a mutation or the initiate a cancer [47].

\section{Conclusion}

In general, the amount of pistachios consumed as ingredient in desserts and ice creams is much higher than a gram, and all samples (100\%) were contaminated with AF. Therefore, the consumption of this seed in years will produce a lot of stored adducts in DNA and this fact can be considered a risk factor for the development of cancer.

\section{Acknowledgment}

The authors would like to thank the Instituto de Biología at Universidad Nacional Autónoma de México (UNAM) for the equipment, administration and facilities provided, and for the funds that financed this research. We disclose any financial, consulting, and personal relationships with other people or organisations that could influence (bias) the author's work. We thank Joel Villavicencio, Jorge López, Alfredo Wong, Diana Martínez and Julio César Montero for their computer assistance and design. Additionally, we thank Georgina Ortega Leite and Gerardo Arévalo for library information and finally to Noemí Chávez of the Technical Secretary, all from the Institute of Biology, UNAM.

\section{References}

1. Set E, Erkmen $O$ (2010) The aflatoxin contamination of ground red pepper and pistachio nuts sold in Turkey. Food Chem Toxicol 48: 2532-2537.

2. FAOSTAT [Food and Agriculture Organization of the United Nations] (2012) Agricultural Production Statistics.

3. ICMSF [International Commission on Microbiological Specifications for Foods] (1996) Toxigenic Fungi: Aspergillus. Academic Press. London, United Kingdom. 
4. Ito Y, Peterson SW, Wicklow DT, Goto T (2001) Aspergillus pseudotamarii, a new aflatoxin producing species in Aspergillus section Flavi. Mycol Res 105 233-239.

5. Peterson SW, Ito Y, Horn BW, Goto T (2001) Aspergillus bombycis a new aflatoxigenic species and genetic variation in its sibling species, A.nomius. Mycologia 93: 689-703.

6. Klich MA, Mullaney EJ, Daly CB, Cary JW (2000) Molecular and physiologica aspects of aflatoxin and sterigmatocystin biosynthesis by Aspergillus tamari and A. ochraceoroseus. Appl Microbiol Biotechnol 53:605-609.

7. IARC [International Agency for Research on Cancer] (2002) Some traditional herbal medicines, some mycotoxins, naphthalene and styrene. Monographs on the Evaluation of Carcinogenic Risks to Humans Lyon, France. 82:171.

8. Llewelyn GS, Stepheson GA, Hoffman JW (1977) AFB 1 toxicity and teratogenicity in Japanese Medaka eggs (Oryzias latipes). Toxicon 15: 582 587

9. Binder EM (2007) Managing the risk of mycotoxins in modern feed production Anim Feed Sci Technol 133: 149- 166.

10. Jeffrey AM, Williams GM (2005) Risk assessment of DNA-reactive carcinogens in food. Toxicol Appl Pharmacol 207: S628-S635.

11. Juan C, Zinedine A, Molto JC, Idrissi L, Manes J (2008) Aflatoxins levels in dried fruits and nuts from Rabat-Salé area, Morocco. Food Control 19: 849-853.

12. Trucksess MW, Scott PM (2008) Mycotoxins in botanicals and dried fruits: a review. Food Addit Contam 25: 181-192.

13. Cheraghali AM, Yazdanpanah H, Doraki N, Abouhossain G, Hassibi M, et al (2007) Incidence of aflatoxins in Iran pistachio nuts. Food Chem Toxicol 45 812- 816.

14. Ghali R, Belouaer I, Hdiri S, Ghorbel H, Maaroufi K, et al. (2009) Simultaneous HPLC determination of aflatoxins B1, B2, G1 and G2 in Tunisian sorghum and pistachios. J Food Compos Anal 22: 751-755.

15. Dini A, Khazaeli P, Roohbakhsh A, Madadlou A, Pourenamdari M, et al. (2013) Aflatoxin contamination level in Iran's pistachio nut during years 2009-2011. Food Control 30: 540- 544.

16. Blesa J, Soriano JM, Moltó JC, Mañes J (2004) Limited survey for the presence of aflatoxins in foods from local market and supermarkets in Valencia, Spain. Food Addit Contam 21: 165-171.

17. El Universal (2012) 20.4 millones in April 6, 2012.

18. COESPO [Consejo Estatal de Población] (2012) Población total del Estado de México por municipio. Secretaría General de Gobierno. (Accessed April 5 , 2014)

19. Inegi [Instituto Nacional de Estadística y Geografía] (2010) Delimitación de las zonas Metropolitanas de México 2010.

20. Benford D, Leblanc JC, Setzer RW (2010) Application of the margen of exposure (MoE) approach to substances in food that are genotoxic and carcinogenic. Example: Aflatoxin B1 (AFB1). Food Chem Toxicol 48: S34-S41.

21. Cucullu AF, Lee LS, Mayne RY, Goldblatt LA (1966) Determination of aflatoxins in individual peanut and peanut sections. J Am Oil Chem Soc 43:89.

22. Whitaker TB, Dowell FE, Hagler Jr WM, Giesbrech FG, Wu J (1994) Variability associated with sampling, sample preparation, and chemical testing of farmers stock peanuts. J Assoc off Anal Chem Int 77:107-116.

23. Schatzki TF, Toyofuku N (2004) Sampling and sample preparation of pistachios in Proceedings Meeting. The Mycotoxin Menace. Barug D, Van Egmond HP, López García R, Van Osenbruggen WA, Visconti A (eds).Wageningen Academic Publishers, The Netherlands.

24. Steiner WE, Brunschweiler K, Leimbacher E, Scheneider R (1992) Aflatoxins and fluorescence in Brazil nuts and pistachio nuts. J Agric Food Chem 40: 2453- 2457.

25. Micotti da Gloria E (2011) Aflatoxin contamination distribution among grains and nuts, aflatoxins-detection, measurement and control, Irineo Torres-Pacheco, INTECH Open Access Publisher ISBN: 978-953-307-711-6. Accessed Oct 31 st, 2014

26. Baltaci C, llyasoğlu $H$, Yüksel $F$ (2013) Single-laboratory validation for the determination of Aflatoxin $B, B, G$, and $G$ in foods based on immunoaffinity column and liquid chromatography with post column derivatization and fluorescence detection. Food Anal Methods 6: 36- 44
27. MSCR, Ministerio de Salud de Costa Rica (2002) Guía de validación de métodos analíticos. Costa Rica. [MSCR, Ministry of Health of Costa Rica (2002) Validation guide for analytical methods. Costa Rica]

28. AOAC [Association of Official Analytical Chemist International] (2005) Natura toxins. Chapter 49. In: Trucksess, M.W. Chapter editor. Official Methods of Analysis of AOAC International. Maryland, USA. 1-99.

29. Akiyama H, Goda Y, Tanaka T, Toyoda M (2001) Determination of aflatoxins $B$ $B_{2}, G_{1}$ and $G_{2}$ in spices using a multifunctional column clean-up. J Chromatogr A 932: 153-157.

30. Norma Oficial Mexicana [NOM-188-SSA1-2002] (2002) Norma Oficia Mexicana, productos y servicios. Control de aflatoxinas en cereales para consumo humano y animal. Especificaciones sanitarias, 41. México, D.F.

31. Jaimez J, Fente CA, Vazquez BI, Franco CM, Cepeda A, et al. (2000) Application of the assay of aflatoxins by liquid chromatography with fluorescence detection in food analysis. J Chromatogr A, 882: 1-10.

32. Papp E, H-Otta K, Záray G, Mincsovic E (2002) Liquid chromatography determination of aflatoxins. Microchem J 73: 39-46.

33. FAO [Food and Agriculture Organization of the United Nations] (2004) Worldwide regulations for mycotoxins in food and feed in 2003. FAO Food and Nutrition Paper, 81. Rome, Italy.

34. Doster MA, Michailides TJ (1994) Aspergillus molds and aflatoxins in pistachio nuts in California. Phytopathology 84: 583-590.

35. Mahoney NE, Rodriguez SB (1996) Aflatoxin variability in pistachios. Appl Environ Microbiol 62: 1197-1202.

36. Carvajal M, Espinosa J, Moctezuma G, Gonsebatt ME, Pérez I (2004) Minimal amount of AFB to produce a mutation in Ames test with Salmonella typhimurium TA-98. Rev Mex Micol 19: 71-79.

37. Heperkan D, Aran N, Ayfer M (1994) Mycoflora and aflatoxin contamination in shelled pistachio nuts. J Sci Food Agric 66: 273-278.

38. Georgiadou M, Dimou A, Yanniotis S (2012) Aflatoxin contamination in pistachio nuts: A farm to storage study. Food Control 26: 580-586.

39. Kurtzman CP, Horn BW, Hesseltine CW (1987) Aspergillus nomius, a new aflatoxins-producing species related to Aspergillus flavus and Aspergillus tamarii. Antonie Van Leeuwenhoek 53: 147-158.

40. Goto T, Wiclow DT, Ito Y (1996) Aflatoxin and cyclopiazonic acid production by a sclerotium producing Aspergillus tamarii strain. Appl Environ Microbiol 113: 4036-4038.

41. Ehrlich K, Cotty PJ (2003) New insights into $\mathrm{pH}$ regulation of AF production by Aspergillus species. XXII Fungal Genetics Conference Proceedings, Abstract 201: 1-283.

42. Gebauer SK, West SG, Kay CD, Alaupovic P, Bagshaw D, et al. (2008) Effects of pistachios on cardiovascular disease risk factors and potential mechanisms of action: A dose-response study. Am J Clin Nutr 88: 651-659.

43. Sari I, Baltaci Y, Bagci C, Davutoglu V, Erel O, et al. (2010) Effect of pistachio diet on lipid parameters, endothelial function, inflammation, and oxidative status: A prospective study. Nutrition 26: 399-404.

44. Molyneux RJ, Mahoney N, Kim JH, Campbell BC (2007) Mycotoxins in edible tree nuts. Int J Food Microbiol 119: 72-78.

45. Phillips JC, Davies S, Lake BG (1999) Dose-response relationships for hepatic aflatoxin B1-DNA adduct formation in the rat in vivo and in vitro: the use of immunoslot blotting for adducts quantitation. Teratog Carcinog Mutagen 19 157-170.

46. Essigmann JM, Croy RG, Bennett RA, Wogan GN (1982) Metabolic activation of aflatoxin $\mathrm{B}_{1}$ : Patterns of DNA adduct formation, removal, and excretion in relation to carcinogenesis. Drug Metab Rev 13: 581-602.

47. Shupe T, Sell S (2004) Low hepatic glutathione S-transferase and increased hepatic DNA adduction contribute to increased tumorigenicity of Aflatoxin B1 in newborn and partially hepatectomized mice. Toxicol Lett 148: 1-9. 